\title{
Sources of Resistance to the Maize Weevil Sitophilus zeamais in Tropical Maize
}

\author{
Mwololo J. K. ${ }^{1,2}$, Mugo S. ${ }^{3}$, Okori P. ${ }^{1}$, Tefera T. ${ }^{3}$, Otim M. ${ }^{4}$ \& Munyiri S. W. ${ }^{1,5}$ \\ ${ }^{1}$ Makerere University, Kampala, Uganda \\ ${ }^{2}$ Pwani University College, Kilifi, Kenya \\ ${ }^{3}$ International Maize and Wheat Improvement Center (CIMMYT), Village Market, Nairobi, Kenya \\ ${ }^{4}$ National Crops Resources Research Institute, Namulonge, Kampala, Uganda \\ ${ }^{5}$ Chuka University College, Chuka, Kenya \\ Correspondance: Stephen Mugo, International Maize and Wheat Improvement Center (CIMMYT), Village \\ Market, Nairobi, Kenya. E-mail: s.mugo@cgiar.org
}

Received: July 26, 2012 Accepted: August 14, 2012 Online Published: October 12, 2012

doi:10.5539/jas.v4n11p206 URL: http://dx.doi.org/10.5539/jas.v4n11p206

\begin{abstract}
The maize weevil, Sitophilus zeamais (Motschulsky) (Coleoptera: Curculionidae), is among the major storage pests that enhance food insecurity among maize farmers. New sources of resistance to the maize weevil are critical in a successful breeding program to address grain damage by postharvest pests. The objective of the study was to evaluate resistance in maize genotypes to the maize weevil, and consequently their value for use in breeding programs. A total of 175 genotypes, including hybrids, landraces, open-pollinated varieties and checks, were tested for resistance to the maize weevil. The percentage grain damage, weight loss, flour weight and weight of damaged and undamaged grains were measured. Significant differences $(P<0.001)$ were observed among the genotypes for all the traits evaluated. The distribution of the genotypes among the different categories of resistance was an indication of the existence of genetic variation. The most resistant genotypes were CKPH08003 and BRAZ 2451 while the most susceptible were PH 3254 and BRAZ 4, among the hybrids and landraces respectively. Genotypes that were superior to the resistant checks were identified. The percentage weight loss and flour weight were identified as the most important insect-resistance traits for discriminating genotypes as evident from the canonical discriminant analysis. Correlation coefficients among the traits evaluated were highly significant. The resistant hybrids identified can be recommended for release and adoption by farmers, whereas the resistant landraces can act as sources of resistance for use in breeding programs.
\end{abstract}

Keywords: Maize weevil, Sitophilus zeamais, postharvest pests, pest resistance, tropical maize

\section{Introduction}

Over half of Africans earn their livelihood from agriculture (Pretty et al., 2011). Despite this, tropical African countries are among the most food-insecure in the world (Sasson, 2012). Food security could be achieved through enhancing agricultural productivity and by reducing field and postharvest crop losses. Agricultural production is seasonal, while the demand for agricultural commodities is evenly spread throughout the year. Crop storage for future use, therefore, becomes important (Thamaga-Chitja et al., 2004). Maize is an essential component of the global food security and forms a major part of the diet of millions of people. In Africa, maize is primarily grown by small-scale farmers for use as both food and feed. Its productivity is thus critical to raising rural incomes and stimulating broad-based economic growth (Byerlee et al., 1997). Maize grain storage is crucial and needed in order to maintain constant supply through- out the year. For small-scale farmers in Africa, the main purpose of storage is to ensure household food supplies and seed for planting (Adetunji, 2007).

Stored grains may suffer serious attack from pests (insects, rodents and birds) and pathogens (bacteria and fungi), especially when not protected and when storage hygiene is poor. Amidst other constraints of maize production, insect pests constitute a major threat, destroying approximately $20 \%$ of food produce (Pimentel, 2007). The damage caused by postharvest pests is much higher than that caused by other agents like rodents and micro-organisms. The maize weevils, Sitophilus zeamais (Motschulsky) (Coleoptera: Curculionidae), the Angoumois grain moth, Sitotroga cerealella (Olivier) (Lepidoptera: Gelechiidae) and the larger grain borer 
Prostephanus truncatus (Horn) (Coleoptera: Bostrichidae) are the most important postharvest pests of stored cereal grains (Abate et al., 2000). In fact, in addition to direct destruction of grains through feeding and reproduction, the presence of insects has direct influence on grains, causing an increase in grain temperature and moisture contents. These lead to an increase in respiration and consequent loss in quantity and quality of the grain (Odogola, 1994). This pre-disposes the stored grain to secondary attack by disease-causing pathogens such as mycotoxin-producing fungi. The postharvest losses due to the Sitophilus zeamais have been recognized as an important constraint, with grain losses ranging from 20 - 90\% being reported for stored untreated maize grains (Derera et al., 2001; Tefera et al., 2011a). The damage caused is irreversible and affects both farmers and traders. The adults and the larvae of the weevils are internal feeders on the maize grains and this affects seed viability and successful planting by small-scale farmers. Meeting the ever-increasing demand for sufficient quantity and acceptable quality of food, therefore, requires a reduction in damage from insects that attack the stored maize grain and seed.

Different technologies have proven effective in controlling storage insect pests, such as environmental manipulations to hinder their growth, maturation and reproduction. Such environmental manipulations can be attained by employing a number of control measures, including the use of pesticides, cultural and physical control measures (Pereira et al., 2009). Pesticides are effectively used against postharvest insect pests but are often associated with a number of drawbacks including high costs, environmental pollution and food safety, and the occurrence of resistance in the insect pests (Asawalam et al., 2006). Host-plant resistance through genetic improvements remains a cornerstone of an integrated pest-management strategy to minimize storage losses and impact on grain quality. Breeding for resistance to postharvest insect pests was initially ignored, probably due to the long duration from crop establishment to postharvest screening for resistance and the high cost involved. Genetic variation and the heritability of resistance maize weevil and other storage pests have been reported (Derera et al., 2001; Mwololo et al., 2010). This raises hope for the possibility of introducing weevil-resistance traits into elite maize germplasm. Effective breeding for resistance requires identifying resistant materials in the maize gene pool and understanding the mechanisms of resistance.

Progress has been made in developing maize cultivars resistant to post-harvest insect pests. However, the current resistance is based on a narrow source of an unimproved gene bank accession. Moreover, the current insect-resistant germplasm is not adequate since the varieties developed are lacking in one or more of the farmer-preferred agronomic traits. Breeding progress in relation to postharvest pests would depend on the extent of genetic variability within the maize germplasm. The higher the variability for a given trait, the higher the genetic gain would be expected from the selection process. There is need to search for more sources of resistance among adapted genotypes within the tropics. The use of resistant varieties against storage insect pests, when successful, would have a number of comparative advantages over other control measures, particularly the use of pesticides which have a range of shortcomings (Gemechu et al., 2011). The objective of the study was, therefore, to assess the reaction of maize hybrids, open pollinated varieties (OPVs) and landraces to maize weevil infestation and damage in order to identify sources of resistance for use in breeding programs and for deployment to farmers.

\section{Materials and Methods}

\subsection{Germplasm}

A total of 175 genotypes were used in the study, including hybrids, open-pollinated varieties (OPVs) and landraces. The 87 hybrids used comprised of commercial, drought-tolerant and quality protein maize genotypes from the International Maize and Wheat Improvement Center (CIMMYT) breeding program. The thirteen (13) OPVs and 75 landraces used in this study were sourced from the CIMMYT gene bank in Mexico. Two hybrid checks, CKPH09001 (resistant) and H513 (susceptible) checks were included in the study.

\subsection{Experimental Sites}

Field trials were established at the Kiboko and Embu centers of the Kenya Agricultural Research Institute (KARI). Kiboko is a dry, mid-altitude agro-ecological zone, located at $37^{\circ} 75^{\prime} \mathrm{E}$ and $2^{\circ} 15^{\prime} \mathrm{S}$, situated at about 975 masl. Average rainfall in Kiboko is $530 \mathrm{~mm}$, with mean monthly maximum temperature of $35.1^{\circ} \mathrm{C}$ and a minimum of $14.3^{\circ} \mathrm{C}$ and has sandy clay soils. Embu is a moist, mid-altitude zone at 1,350 masl, located at $37^{\circ}$ $42^{\prime} \mathrm{E}$ and $0^{\circ} 49^{\prime} \mathrm{S}$. The average rainfall in Embu is $1,200 \mathrm{~mm}$ with a mean monthly maximum and minimum temperature of $25^{\circ} \mathrm{C}$ and $14.1^{\circ} \mathrm{C}$ and has clay loam soils.

\subsection{Experimental Design}

The hybrids and OPVs were planted in one trial due to their similarity in architecture, while the landraces were 
planted in a separate trial. The genotypes were replicated three times in a $20 \times 5$ and $15 \times 5$ alpha lattice design in $2 \times 5 \mathrm{~m}$ row plots, for the hybrids and OPVs trial and for the landraces trial, respectively. Two seeds were planted per hill and later thinned to one, giving a plant density of 53,333 plants per hectare. In order to ensure a healthy crop, agronomic practices including weeding, fertilizer application, stem borer control and supplemental irrigation were done when necessary. At harvest, the maize was shelled and dried to obtain grains for insect-resistance bioassays.

\subsection{Evaluation of Maize Germplasm for Resistance to the Maize Weevil}

The insects used in the experiment were obtained from the KARI/CIMMYT Kiboko Maize Entomology Laboratory where they were reared on the grains of maize cultivar PH3253 under controlled conditions $\left(28^{\circ} \mathrm{C}\right.$ and $75 \%$ relative humidity $(\mathrm{RH})$. The maize grains were sun-dried to a moisture content of $12-13 \%$ and disinfested by fumigating with phostoxin tablets for seven days in a drum to eliminate field infestation. Samples of 100 grams of grain were taken from each plot of the three replications. The kernels were placed in $250 \mathrm{ml}$ jars, infested with 50 unsexed 7-10 days old maize weevils, and incubated for 3 months at $26-28^{\circ} \mathrm{C}$ and $70-75 \%$ relative humidity in the Entomology Laboratory at KARI/CIMMYT Kiboko. The experimental design in the laboratory was a completely randomized design replicated three times.

The contents of each jar were sieved with mesh sieves (Endecotts Ltd, UK ${ }^{1}$ ) 3 months after infestation to separate grains, insects and flour. The flour produced was measured with a weighing balance while the number of damaged kernels and adult insect progeny were counted. The grain weight loss was computed by subtracting the final from the initial weight of the grain sample and expressed as a percentage (Tefera et al., 2011b). The damaged kernels were separated from the undamaged ones using grain tunneling and holes as the criteria. These were counted and the percentage of damaged grain computed. The weight of the damaged and undamaged grains was measured. The parameters used for the maize weevil resistance assessment were the percentage weight loss, the grain damage percentage, the flour weight, and the number of insects recovered (Tefera et al., 2011b).

\subsection{Statistical Analyses}

A multivariate analysis of variance within a canonical variate analysis (Canonical Discriminant Analysis) was performed using statistical analysis system software (SAS) to determine the difference between genotypes and the most variable insect resistance trait among the genotypes. A univariate analysis of variance (ANOVA) for the individual resistance traits was done using the general linear model (GLM) procedure of SAS (SAS Institute, 2003). The number of insects was $\log$ transformed $\left(\log _{10}\right)$, while flour produced, grain damage, weight of damaged and undamaged grains and weight loss were angular transformed to normalize their distribution before subjecting them to analysis of variance. The insect-damage traits were correlated using a canonical correlation to obtain error control and identify the strongest correlation.

\section{Results}

\subsection{Discriminant Analysis}

The ANOVA option specifies testing the hypothesis that the class means are equal using univariate statistics. The $\mathrm{R}^{2}$ values ranged from 0.4 for the grain damage to 0.54 for the percentage flour weight and all the variables were significant at $P=0.05$ (Table 1). The multivariate test for differences between the classes was also significant at $P=0.05$ level, therefore, the multivariate tests of the hypothesis that the class mean vectors were equal indicate that they were not $(\mathrm{P}<0.001)$ (Table 1). The linear combination of the centered variables were $(\mathrm{CAN} 1) 0.5438 \times$ No. Insects $+0.7323 \times$ Flour weight $+0.6272 \times$ weight of damaged grains $-0.8385 \times$ weight of undamaged grains + $0.7805 \times$ weight loss $+0.5863 \times$ grain damage which separates the entries most effectively (Table 1$)$. In the first canonical variate, weight loss and/or flour weight were indicated as the most important variables for discriminating among genotypes for they had the largest coefficients. These were used to calculate the susceptibility indices as described by Tefera et al. (2011c): summing the ratio between the genotype mean values and grand means of the traits in question; divided by 2 (the number of variables). The genotypes with susceptibility index values less than 0.7 were regarded as highly resistant, $0.7-0.8$ as resistant, $0.8-1.2$ as moderately susceptible and $>1.21$ as highly susceptible. The coefficient of the weight of the undamaged grains was also high but negatively correlated to the other variables hence not suitable for discrimination of the genotypes in relation to resistance.

\subsection{Resistance of Maize Hybrids and OPVs to the Sitophilus Zeamais}

There were significant differences $(\mathrm{P}<0.01)$ among the hybrids for grain damage, weight loss, flour weight, number of adult insects, weight of damaged and undamaged grains (Table 2). The genotype $\times$ location interaction was not significant for all the traits evaluated (Table 2). The genotypes were categorized as resistant, moderately resistant, moderately susceptible and highly susceptible based on the susceptibility index which was 
computed based on the flour weight and weight loss as these were indicated as the most important traits for discrimination by the canonical discriminant analysis. The resistant genotypes had low percentage of flour weight, number of insects and high weight of undamaged grains (Table 2).

The classification shows that the genotypes were not normally distributed probably due to the fact that they were deliberately selected (Figure 1). The highly resistant and moderately resistant represented 39\% of the hybrids evaluated, $36 \%$ were moderately susceptible and $25 \%$ highly susceptible. The most resistant genotype among the hybrids was CKPH08003 with susceptibility index of 0.40 which was five times lower than that of PH 3252 the most susceptible hybrid. The percentage weight loss and flour weight of the most resistant was three-fold lower than that of the most susceptible genotype and twice lower than the mean of all the genotypes. The numbers of insects were higher in the most susceptible and lower among the resistant genotypes. The resistant check CKPH9001 had a susceptibility index of 0.60 which was higher than that of the 11 genotypes categorized as the most resistant. Most of the resistant genotypes were the CIMMYT hybrids which had been bred for storage pest resistance. The most susceptible genotypes had a susceptibility index of 2.2 which was 1.9 times higher than that of the susceptible check (H513).

Table 1. Canonical discriminant analysis parameters for the number of emerged weevils, flour and grain weight, weight loss and grain damage in the 175 maize hybrids, OPVs and landraces

\begin{tabular}{ccccccccc}
\hline Variable & Pooled SD & Between SD & R-Square & F Value & Pr $>$ F & Can 1 & Can 2 & Can 3 \\
\hline Number of insects & 125.97 & 85.60 & 0.41 & 1.39 & 0.0273 & 0.5438 & 0.4247 & 0.1310 \\
Flour weight (\%) & 1.47 & 1.32 & 0.54 & 2.42 & $<.0001$ & 0.7323 & 0.5994 & -0.1637 \\
Weight-DG (\%) & 15.46 & 11.95 & 0.47 & 1.79 & 0.0003 & 0.6272 & 0.3225 & 0.5808 \\
Weight-UDG (\%) & 20.87 & 17.97 & 0.52 & 2.23 & $<.0001$ & -0.8385 & -0.1525 & -0.3018 \\
Weight loss (\%) & 10.03 & 8.08 & 0.49 & 1.94 & $<.0001$ & 0.7805 & -0.0894 & -0.2350 \\
Grain damaged (\%) & 14.87 & 9.96 & 0.40 & 1.35 & 0.0401 & 0.5863 & -0.1465 & 0.3596 \\
\hline
\end{tabular}

Note: Can $=$ Canonical variable coefficient; $\mathrm{SD}=$ Standard deviation; $\mathrm{GD}=$ grain damage

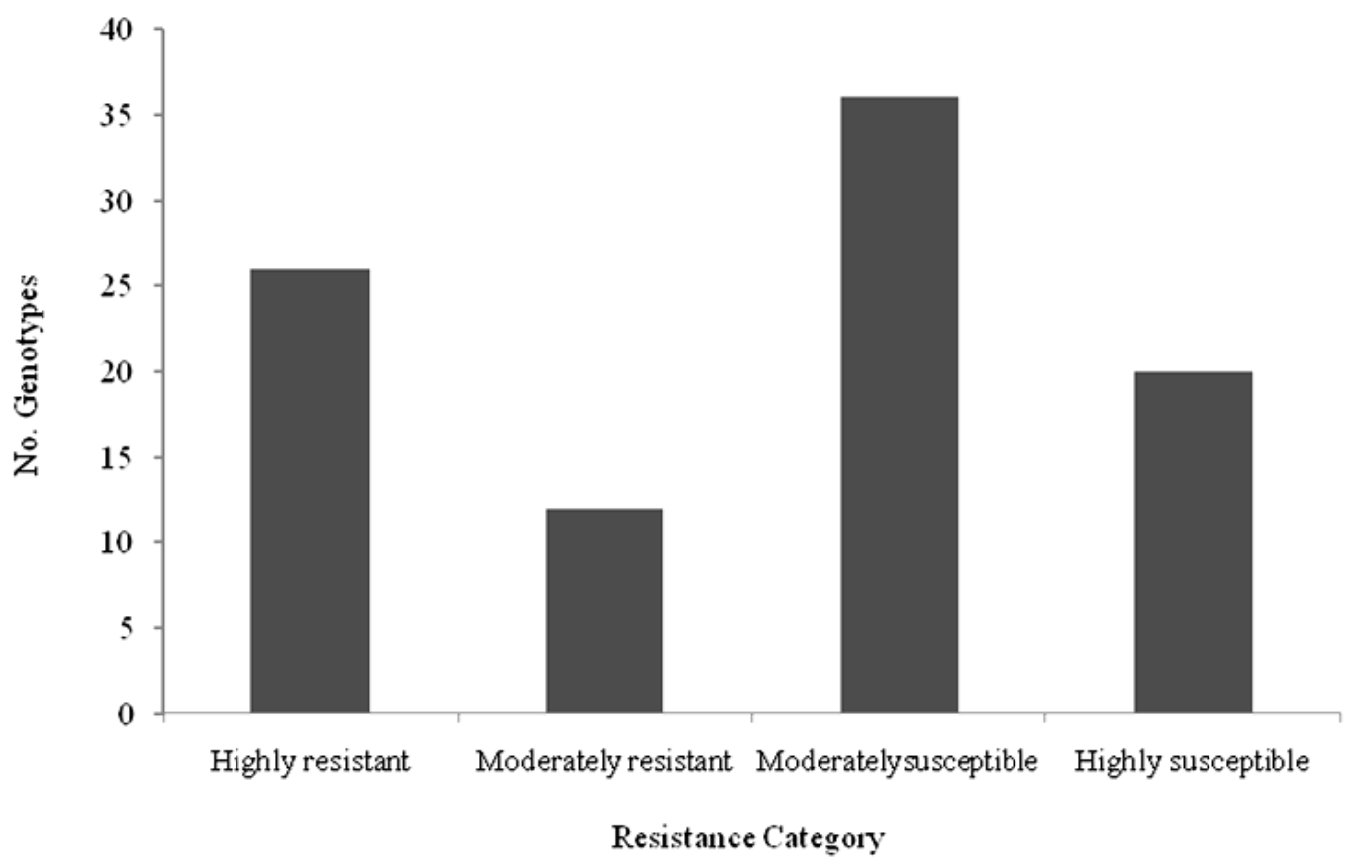

Figure 1. The distribution of genotypes according to resistance categories in the 87 maize hybrids and 13 OPVs 
Table 2. Number of emerged weevils, flour and grain weight loss, grain damage and susceptibility indices for the 20 most resistant and 20 most susceptible maize hybrids and OPVs

\begin{tabular}{|c|c|c|c|c|c|c|c|c|}
\hline Entry & $\begin{array}{c}\text { Genoty } \\
\text { pe }\end{array}$ & $\begin{array}{l}\text { No. of } \\
\text { Insects }\end{array}$ & $\begin{array}{c}\text { Flour } \\
\text { weight }(\%)\end{array}$ & $\begin{array}{l}\text { Weight Damaged } \\
\text { grains }(\%)\end{array}$ & $\begin{array}{l}\text { Weight Undamaged } \\
\text { grains }(\%)\end{array}$ & $\begin{array}{l}\text { Weight } \\
\text { loss }(\%)\end{array}$ & $\begin{array}{c}\text { Grain } \\
\text { damage } \\
(\%)\end{array}$ & $\begin{array}{l}\text { Susceptibilit } \\
\text { y Index }\end{array}$ \\
\hline 67 & $\begin{array}{l}\text { CKPH0 } \\
8003\end{array}$ & 68.92 & 0.48 & 14.28 & 79.48 & 6.24 & 23.50 & 0.40 \\
\hline 69 & $\begin{array}{c}\text { CKPH0 } \\
9004\end{array}$ & 73.83 & 0.55 & 19.91 & 73.70 & 6.38 & 28.56 & 0.42 \\
\hline 70 & $\begin{array}{c}\text { CKPH0 } \\
8009\end{array}$ & 83.00 & 0.55 & 15.91 & 77.25 & 6.84 & 25.89 & 0.44 \\
\hline 71 & $\begin{array}{c}\text { CKPH0 } \\
8010\end{array}$ & 60.00 & 0.61 & 15.29 & 78.20 & 6.51 & 25.08 & 0.45 \\
\hline 78 & $\underset{8028}{\text { CKPH0 }}$ & 84.67 & 0.68 & 14.25 & 79.73 & 6.02 & 26.48 & 0.46 \\
\hline 77 & $\underset{8026}{\mathrm{CKPH0}}$ & 80.75 & 0.68 & 18.46 & 74.74 & 6.80 & 19.71 & 0.48 \\
\hline 57 & $\underset{8035}{\text { CKPH0 }}$ & 83.83 & 0.62 & 20.39 & 71.82 & 7.79 & 32.29 & 0.50 \\
\hline 73 & $\underset{8014}{\text { CKPH0 }}$ & 72.08 & 0.73 & 15.96 & 77.11 & 6.92 & 19.92 & 0.51 \\
\hline 59 & $\begin{array}{c}\text { CKPH0 } \\
8037\end{array}$ & 83.17 & 0.66 & 15.93 & 76.27 & 7.80 & 29.62 & 0.52 \\
\hline 72 & $\begin{array}{c}\text { CKPH0 } \\
8012\end{array}$ & 66.92 & 0.68 & 17.53 & 74.72 & 7.75 & 25.79 & 0.52 \\
\hline 75 & $\underset{8024}{\text { CKPH0 }}$ & 62.17 & 0.79 & 14.73 & 78.39 & 6.88 & 20.73 & 0.52 \\
\hline 76 & $\underset{8025}{\text { CKPH0 }}$ & 81.00 & 0.70 & 16.75 & 74.73 & 8.52 & 28.28 & 0.56 \\
\hline 62 & $\underset{8040}{\text { CKPH0 }}$ & 71.42 & 0.80 & 20.93 & 70.24 & 8.83 & 29.84 & 0.60 \\
\hline 23 & $500 \mathrm{Q}$ & 92.50 & 0.89 & 17.69 & 74.16 & 8.21 & 33.63 & 0.61 \\
\hline 54 & $\begin{array}{l}\text { CKPH0 } \\
9002\end{array}$ & 114.42 & 0.81 & 26.70 & 63.62 & 9.68 & 44.02 & 0.64 \\
\hline 68 & $\underset{8004}{\mathrm{CKPH0}}$ & 96.17 & 0.90 & 17.65 & 73.31 & 9.04 & 23.76 & 0.64 \\
\hline 49 & $\begin{array}{l}\text { CKIR0 } \\
6007\end{array}$ & 89.58 & 0.94 & 21.36 & 69.84 & 8.80 & 30.47 & 0.65 \\
\hline 55 & CKPH0 & 103.08 & 0.92 & 25.68 & 65.12 & 9.21 & 42.54 & 0.66 \\
\hline 53 & $\underset{8032}{\mathrm{CKPH} 0}$ & 100.08 & 0.87 & 26.58 & 63.73 & 9.70 & 40.08 & 0.66 \\
\hline 66 & CKPH0 & 101.25 & 0.95 & 23.84 & 67.01 & 9.15 & 26.34 & 0.66 \\
\hline 63 & $\underset{8041}{\mathrm{CKPH} 0}$ & 106.08 & 1.03 & 19.32 & 71.99 & 8.69 & 25.91 & 0.67 \\
\hline Mean & & 84.52 & 0.75 & 19.01 & 73.10 & 7.89 & 28.69 & 0.55 \\
\hline $\begin{array}{l}\text { Resistant } \\
\text { check }\end{array}$ & CKPH0 & 78.08 & 0.72 & 24.21 & 66.26 & 9.53 & 38.56 & 0.60 \\
\hline 29 & $\begin{array}{c}\text { CKIR0 } \\
7017\end{array}$ & 155.42 & 2.42 & 41.54 & 44.17 & 14.29 & 45.48 & 1.35 \\
\hline 38 & $\begin{array}{l}\text { CKIR0 } \\
9001\end{array}$ & 234.67 & 2.33 & 39.39 & 43.62 & 16.99 & 53.88 & 1.42 \\
\hline 46 & $\begin{array}{c}\text { CKIR0 } \\
6001\end{array}$ & 194.25 & 2.49 & 35.04 & 49.04 & 15.92 & 34.80 & 1.44 \\
\hline $\begin{array}{l}11 \\
21\end{array}$ & $\begin{array}{c}\text { DHO4 } \\
531 \mathrm{~A} \\
\text { SC }\end{array}$ & $\begin{array}{l}230.83 \\
222.08\end{array}$ & $\begin{array}{l}2.26 \\
2.50\end{array}$ & $\begin{array}{l}39.69 \\
50.12\end{array}$ & $\begin{array}{l}42.06 \\
33.44\end{array}$ & $\begin{array}{l}18.25 \\
16.44\end{array}$ & $\begin{array}{l}72.79 \\
60.63\end{array}$ & $\begin{array}{l}1.45 \\
1.46\end{array}$ \\
\hline 14 & Duma & 205.08 & 2.52 & 50.95 & 31.33 & 17.72 & 59.03 & 1.51 \\
\hline 44 & $\begin{array}{l}\text { CKIR0 } \\
9007\end{array}$ & 211.17 & 2.56 & 38.57 & 44.01 & 17.42 & 48.93 & 1.52 \\
\hline 36 & $\begin{array}{c}\text { CKIR0 } \\
7008 \\
K H\end{array}$ & 190.42 & 2.32 & 43.39 & 35.23 & 21.38 & 66.35 & 1.58 \\
\hline 18 & $\begin{array}{c}600-15 \\
A\end{array}$ & 192.25 & 2.22 & 42.40 & 35.27 & 22.33 & 67.27 & 1.59 \\
\hline 6 & H626 & 230.83 & 2.63 & 50.57 & 29.73 & 19.70 & 64.99 & 1.63 \\
\hline 33 & $\begin{array}{c}\text { CKIR0 } \\
7003\end{array}$ & 198.00 & 2.76 & 35.41 & 45.41 & 19.18 & 54.92 & 1.65 \\
\hline $\begin{array}{l}4 \\
3\end{array}$ & $\begin{array}{l}\text { H629 } \\
\text { H6210 }\end{array}$ & $\begin{array}{l}210.75 \\
226.92\end{array}$ & $\begin{array}{l}2.22 \\
2.58\end{array}$ & $\begin{array}{l}48.15 \\
53.88\end{array}$ & $\begin{array}{l}27.75 \\
23.82\end{array}$ & $\begin{array}{l}24.11 \\
22.31\end{array}$ & $\begin{array}{l}71.84 \\
81.29\end{array}$ & $\begin{array}{l}1.66 \\
1.71\end{array}$ \\
\hline 24 & $\begin{array}{c}D K 803 \\
1\end{array}$ & 194.67 & 3.29 & 42.04 & 39.41 & 18.55 & 61.74 & 1.80 \\
\hline $\begin{array}{l}5 \\
2\end{array}$ & $\begin{array}{c}H 628 \\
H 6212 \\
\text { SC }\end{array}$ & $\begin{array}{l}196.67 \\
268.25\end{array}$ & $\begin{array}{l}2.72 \\
2.80\end{array}$ & $\begin{array}{l}48.68 \\
50.21\end{array}$ & $\begin{array}{l}22.38 \\
22.16\end{array}$ & $\begin{array}{l}27.08 \\
27.63\end{array}$ & $\begin{array}{l}69.91 \\
78.41\end{array}$ & $\begin{array}{l}1.94 \\
1.98\end{array}$ \\
\hline 13 & $\underset{41}{\text { Duma }}$ & 284.33 & 3.28 & 52.29 & 24.18 & 23.53 & 67.96 & 1.99 \\
\hline $\begin{array}{c}17 \\
1\end{array}$ & $\begin{array}{l}611 D \\
H 6213\end{array}$ & $\begin{array}{l}285.00 \\
261.67\end{array}$ & $\begin{array}{l}3.20 \\
3.44\end{array}$ & $\begin{array}{l}49.14 \\
56.41\end{array}$ & $\begin{array}{l}26.54 \\
19.92\end{array}$ & $\begin{array}{l}24.32 \\
23.67\end{array}$ & $\begin{array}{l}69.58 \\
80.00\end{array}$ & $\begin{array}{l}1.99 \\
2.05\end{array}$ \\
\hline 16 & $\begin{array}{c}P H \\
3253\end{array}$ & 255.75 & 3.96 & 47.43 & 29.76 & 22.80 & 73.35 & 2.19 \\
\hline Mean & & 222.45 & 2.72 & 45.76 & 33.46 & 20.68 & 64.16 & \\
\hline $\begin{array}{l}\text { Susceptible } \\
\text { Check }\end{array}$ & H513 & 190.08 & 2.17 & 46.26 & 36.73 & 17.01 & 66.88 & 1.40 \\
\hline $\begin{array}{c}\text { CV } \\
\text { P Value }\end{array}$ & & $\begin{array}{l}19.09 \\
<0.001 \\
\end{array}$ & $\begin{array}{l}32.79 \\
<0.001 \\
\end{array}$ & $\begin{array}{l}29.74 \\
<0.001 \\
\end{array}$ & $\begin{array}{l}24.18 \\
<0.001 \\
\end{array}$ & $\begin{array}{l}27.49 \\
<0.001 \\
\end{array}$ & $\begin{aligned} & 34.8 \\
&< 0.001 \\
&\end{aligned}$ & \\
\hline
\end{tabular}

Italicized genotypes are commercial maize hybrids 


\subsection{Resistance of Landrace Accessions to the Sitophilus Zeamais}

There were significant differences $(\mathrm{P}<0.05)$ among the landrace accessions for grain damage, weight loss, flour weight, number of adult insects, weight of damaged and undamaged grains (Table 3). The genotypes were categorized into resistant and susceptible based on the susceptibility indices adapted from the method of Tefera et al., (2011b). This showed great variation for resistance against the maize weevil among the landrace accessions.

The top four most resistant were ranked above one of the resistant checkCKPH09002 which had a susceptibility index of 0.64 and the rest were categorized as moderately resistant (Figure 2). The most susceptible landraces were BRAZ 4 and RIGS GP10 with susceptibility index of 2.34 and 2.22, respectively. Their susceptibility indices were five times higher than that of the most resistant (BRAZ2451) which had a susceptibility index of 0.42 . Among the landrace accessions evaluated, $23 \%$ were highly resistant to moderately resistant, $60 \%$ were moderately susceptible and $17 \%$ were highly susceptible.

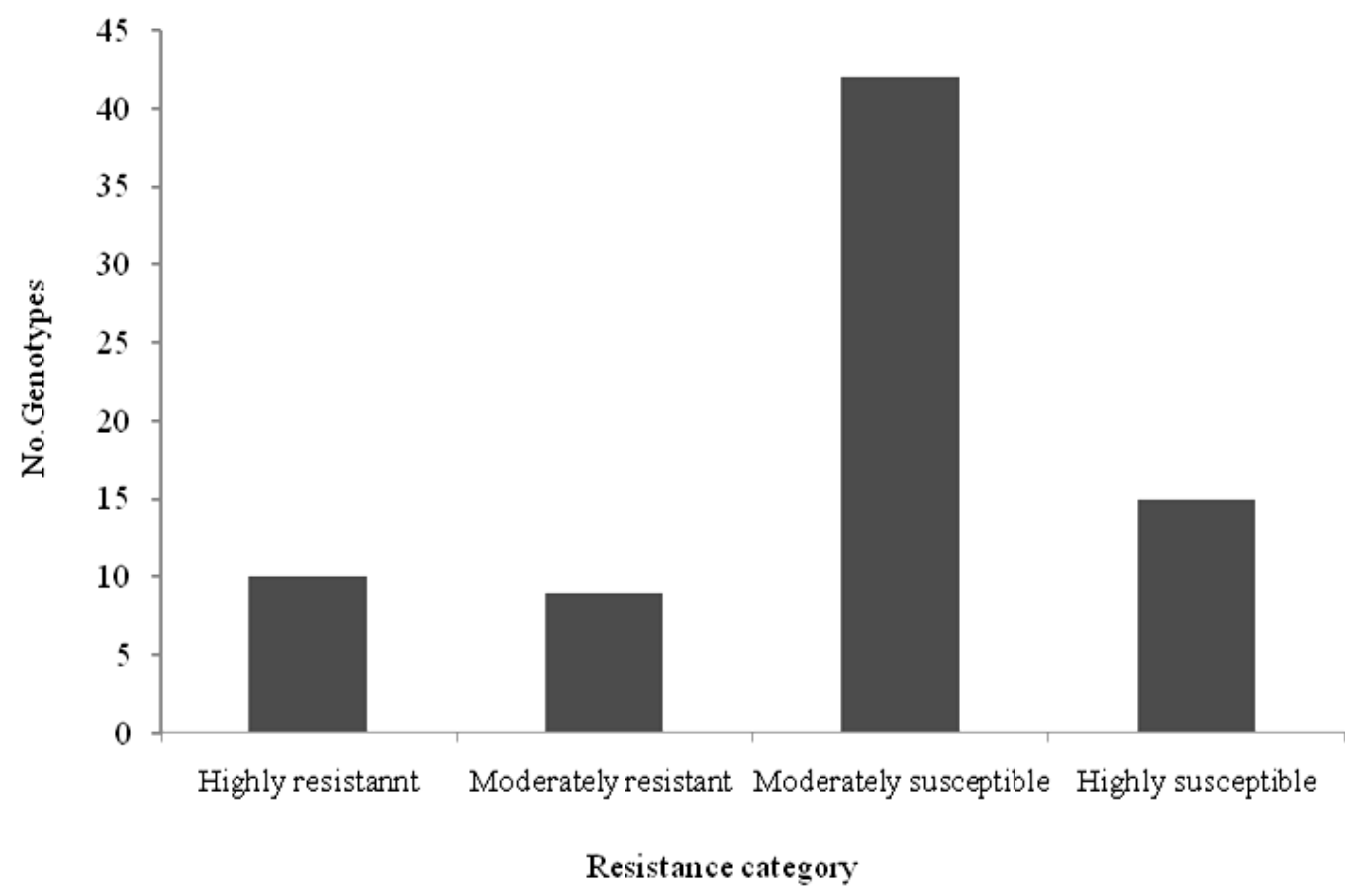

Figure 2. The distribution of genotypes according to resistance categories in the 75 maize landraces

\subsection{Canonical Correlations}

The probability level for the null hypothesis that all the canonical correlations were zero $(0)$ among the variables was highly significant $(P<0.0001)$ hence the two sets of variables were highly correlated. There were great variations in the correlation coefficients between the two sets of variables (Table 4). All the set one variables (number of insects, weight of damaged and undamaged grains) accounted for a substantial amount of shared variance between the two sets of variables. The squared multiple correlation indicate that the first canonical variable of the set one variables has predictive power for number of insects $(\mathrm{r}=0.94)$, weight of damaged grains $(0.90)$ and undamaged grains (-0.95), weight loss (0.96), grain damage (0.95) and flour weight (0.94) (Table 4). The first canonical correlation which is the greatest possible multiple correlation with the classes that can be achieved using a linear combination of the quantitative variables was 0.9730 . The likelihood ratio test for the hypothesis that the current canonical correlation and all the smaller ones are zero show that none of them was zero $(P<0.005)$ and as anticipated, the first line was equivalent to Wilk's Lambda multivariate test $(0.0386)$. The $\mathrm{R}^{2}$ between the first canonical variable (CAN1) and the class variable, 0.95, was much larger than the corresponding $\mathrm{R}^{2}$ for the other two (Table 4). The number of insects and weight of damaged grains were highly and positively correlated to the percentage weight loss, flour weight and grain damage whereas the percentage weight of the undamaged grains was negatively correlated to these. 
Table 3. Number of emerged weevils, flour and grain weight, weight loss, grain damage and susceptibility indices for the 20 most resistant and bottom 20 most susceptible maize landraces

\begin{tabular}{|c|c|c|c|c|c|c|c|}
\hline Entry & Genotype & $\begin{array}{l}\text { No. of } \\
\text { Insects }\end{array}$ & $\begin{array}{l}\text { Weight of damaged } \\
\text { grains }(\%)\end{array}$ & $\begin{array}{l}\text { Weight undamaged } \\
\text { grains }(\%)\end{array}$ & $\begin{array}{c}\text { Flour } \\
\text { weight }(\%)\end{array}$ & $\begin{array}{c}\text { Weight } \\
\text { loss (\%) }\end{array}$ & $\begin{array}{l}\text { Susceptibility } \\
\text { index }\end{array}$ \\
\hline 59 & $\begin{array}{c}\text { BRAZ } \\
2451\end{array}$ & 93.67 & 14.02 & 72.68 & 0.59 & 7.91 & 0.42 \\
\hline 28 & SINA 21 & 99.25 & 21.33 & 70.02 & 0.70 & 8.65 & 0.48 \\
\hline 54 & GUAN 84 & 111.75 & 19.59 & 69.14 & 0.99 & 7.41 & 0.51 \\
\hline 11 & $\begin{array}{c}\text { GUAT } \\
1162\end{array}$ & 131.92 & 22.98 & 67.94 & 1.01 & 9.08 & 0.57 \\
\hline 2 & $\begin{array}{c}\text { GUAT } \\
1008\end{array}$ & 131.50 & 27.31 & 62.70 & 1.15 & 9.99 & 0.64 \\
\hline 53 & GUAN 36 & 133.50 & 24.29 & 65.94 & 1.23 & 9.76 & 0.65 \\
\hline 5 & $\begin{array}{c}\text { GUAT } \\
1100\end{array}$ & 128.00 & 22.49 & 67.02 & 1.21 & 10.50 & 0.67 \\
\hline 44 & GUAT 79 & 145.70 & 21.43 & 67.73 & 1.21 & 10.80 & 0.68 \\
\hline 42 & VENE 897 & 122.58 & 21.74 & 67.44 & 1.29 & 10.82 & 0.70 \\
\hline 27 & $\begin{array}{c}\text { BRAZ } \\
1486\end{array}$ & 105.83 & 30.17 & 57.37 & 1.20 & 12.47 & 0.73 \\
\hline 58 & CHIS 94 & 112.92 & 19.80 & 70.12 & 1.53 & 10.08 & 0.73 \\
\hline 4 & $\begin{array}{c}\text { GUAT } \\
1014\end{array}$ & 144.17 & 23.77 & 64.46 & 1.36 & 11.76 & 0.75 \\
\hline 3 & $\begin{array}{c}\text { GUAT } \\
1010\end{array}$ & 128.58 & 32.07 & 56.22 & 1.38 & 11.71 & 0.75 \\
\hline 52 & GUAN 20 & 185.25 & 33.79 & 53.19 & 1.35 & 13.02 & 0.79 \\
\hline 17 & $\begin{array}{c}\text { BRAZ } \\
2454\end{array}$ & 152.67 & 24.02 & 63.44 & 1.42 & 12.53 & 0.79 \\
\hline 66 & $\begin{array}{c}\text { BRAZ } \\
1736\end{array}$ & 188.83 & 31.35 & 58.30 & 1.75 & 10.35 & 0.80 \\
\hline 57 & VALL 380 & 136.58 & 24.10 & 64.91 & 1.66 & 10.99 & 0.80 \\
\hline 12 & $\begin{array}{c}\text { GUAT } \\
1168\end{array}$ & 156.33 & 25.43 & 61.71 & 1.50 & 12.86 & 0.82 \\
\hline \multirow[t]{2}{*}{35} & $\begin{array}{c}\text { BRAZ } \\
1832\end{array}$ & 166.25 & 30.24 & 56.68 & 1.51 & 13.08 & 0.83 \\
\hline & Mean & 135.90 & 24.88 & 63.62 & 1.27 & 10.88 & 0.70 \\
\hline $\begin{array}{l}\text { Resistant } \\
\text { Check }\end{array}$ & $\begin{array}{c}\text { CKPH0900 } \\
2\end{array}$ & 111.33 & 20.43 & 69.14 & 1.11 & 10.43 & 0.64 \\
\hline 22 & CHIS 114 & 205.42 & 27.93 & 57.93 & 2.24 & 14.14 & 1.05 \\
\hline 20 & SONO 72 & 129.75 & 34.73 & 51.97 & 2.46 & 13.30 & 1.08 \\
\hline 33 & VENE 352 & 172.96 & 30.59 & 53.23 & 2.15 & 16.18 & 1.10 \\
\hline 19 & $\begin{array}{l}\text { BRAZ } \\
2375\end{array}$ & 203.17 & 31.01 & 52.73 & 2.31 & 16.26 & 1.15 \\
\hline 65 & $\begin{array}{c}\text { BRAZ } \\
1495\end{array}$ & 188.33 & 33.97 & 49.83 & 2.33 & 16.20 & 1.15 \\
\hline 7 & GUAT1034 & 172.42 & 26.88 & 57.83 & 2.62 & 15.29 & 1.19 \\
\hline 6 & GUAT1030 & 218.50 & 36.96 & 45.73 & 2.41 & 17.31 & 1.21 \\
\hline 43 & VERA 197 & 164.88 & 35.12 & 46.59 & 2.46 & 18.30 & 1.26 \\
\hline 32 & $\begin{array}{l}\text { BRAZ } \\
2179\end{array}$ & 179.33 & 42.34 & 38.48 & 2.49 & 19.18 & 1.29 \\
\hline 34 & $\begin{array}{c}\text { BRAZ } \\
1364\end{array}$ & 215.00 & 39.42 & 42.96 & 2.74 & 17.62 & 1.30 \\
\hline 61 & NAYA 129 & 195.50 & 38.94 & 41.99 & 2.71 & 19.03 & 1.34 \\
\hline 64 & BRAZ 222 & 163.25 & 32.76 & 48.89 & 2.86 & 18.35 & 1.36 \\
\hline 56 & GUAN 34 & 195.67 & 27.95 & 50.11 & 2.44 & 21.94 & 1.38 \\
\hline 36 & NAYA 130 & 212.42 & 37.36 & 45.17 & 3.17 & 17.47 & 1.40 \\
\hline 21 & $\begin{array}{c}\text { BRAZ } \\
1470\end{array}$ & 224.08 & 33.70 & 44.84 & 3.81 & 21.47 & 1.71 \\
\hline 41 & $\begin{array}{c}\text { BRAZ } \\
1384\end{array}$ & 243.92 & 39.18 & 40.11 & 4.28 & 20.71 & 1.80 \\
\hline 45 & PARA GP3 & 323.02 & 44.74 & 31.85 & 4.62 & 23.44 & 1.98 \\
\hline 55 & PERU 397 & 253.83 & 42.60 & 33.40 & 4.74 & 24.00 & 2.03 \\
\hline 23 & $\begin{array}{l}\text { RIGS } \\
\text { GP10 }\end{array}$ & 294.83 & 41.49 & 32.93 & 5.29 & 25.58 & 2.22 \\
\hline 26 & $\begin{array}{l}\text { BRAZ } 4 \\
\text { Mean }\end{array}$ & $\begin{array}{l}265.25 \\
211.76\end{array}$ & $\begin{array}{l}44.39 \\
36.43\end{array}$ & $\begin{array}{l}33.83 \\
44.77\end{array}$ & $\begin{array}{l}6.27 \\
3.16\end{array}$ & $\begin{array}{l}21.79 \\
18.80\end{array}$ & $\begin{array}{l}2.34 \\
1.45\end{array}$ \\
\hline \multirow[t]{2}{*}{$\begin{array}{l}\text { Susceptible } \\
\text { Check }\end{array}$} & H513 & 190.08 & 46.26 & 36.73 & 2.20 & 17.01 & 1.40 \\
\hline & $\begin{array}{l}\mathrm{CV} \\
\text { P Value }\end{array}$ & $\begin{array}{c}17.87 \\
\mathrm{P}<0.01\end{array}$ & $\begin{array}{c}31.97 \\
\mathrm{P}<0.01\end{array}$ & $\begin{array}{c}30.30 \\
\mathrm{P}<0.01\end{array}$ & $\begin{array}{c}32.50 \\
\mathrm{P}<0.01\end{array}$ & $\begin{array}{c}33.80 \\
\mathrm{P}<0.01\end{array}$ & \\
\hline
\end{tabular}


Table 4. Canonical correlations parameters between set 1 (No. of insects, weight of damaged and undamaged grains) and the set 2 (weight loss, flour weight and grain damage) variables

\begin{tabular}{cccccccccccccccccccccc}
\hline Can & Can corr & SE & $\begin{array}{c}\text { Squared } \\
\text { can corr }\end{array}$ & Eigen value & Variance & Cum variance & LR & F Value & Pr > F & $\begin{array}{c}\text { No. of } \\
\text { insects }\end{array}$ & $\begin{array}{c}\text { Weight } \\
\text { DG (\%) }\end{array}$ & $\begin{array}{c}\text { Weight UDG (\%) } \\
\text { Weight } \\
\text { loss (\%) }\end{array}$ & $\begin{array}{c}\text { Grain } \\
\text { damage (\%) }\end{array}$ & $\begin{array}{c}\text { Flour } \\
\text { weight }(\%)\end{array}$ \\
\hline 1 & 0.9730 & 0.005 & 0.95 & 17.79 & 0.98 & 0.98 & 0.04 & 49.67 & $<.0001$ & 0.9433 & 0.9040 & -0.9580 & 0.962 & 0.949 & 0.958 \\
2 & 0.4330 & 0.082 & 0.19 & 0.23 & 0.01 & 0.99 & 0.73 & 5.43 & $<.0001$ & 0.0064 & 0.1318 & 0.0527 & -0.225 & 0.242 & -0.051 \\
3 & 0.3256 & 0.090 & 0.11 & 0.12 & 0.01 & 1.00 & 0.89 & 5.63 & 0.0049 & 0.0793 & -0.0567 & 0.0389 & -0.153 & -0.201 & 0.281 \\
\hline
\end{tabular}

1. Test of H0: The canonical correlations in the current row and all that follow are zero;

2. Key: Can corr $=$ Canonical correlation; $\mathrm{SE}=\mathrm{Standard}$ error; $\mathrm{Cum}=$ Cumulative; $\mathrm{LR}=$ Likelihood ratio; $\mathrm{DG}=$ damaged grains; $\mathrm{UDG}=$ undamaged grains;

3. *Can: Canonical variable coefficient.

\section{Discussion}

The results from the study show that there is great variation in resistance to the maize weevil in the maize germplasm evaluated. The percentage weight loss was the most important variable for discriminating germplasm for resistance to the maize weevil. The flour weight, number of emerged insects at the end of screening period, and percentage grain damage in that order, were highly correlated as indicated by the canonical correlation analysis. Consequently, these four variables can be integrated to calculate a susceptibility index as reported by Tefera et al. (2011c). The resistant genotypes had low percentage of weight loss, grain damage and reduced number of insects. The low weight loss among the resistant genotypes indicates that mechanisms conferring resistance against the maize weevil exist. The resistance could either be due to physical factors such as grain hardness or antibiosis as a result of biochemical compounds which are toxic to the insects (García-Lara et al., 2004; Siwale et al., 2009). As reported by Abraham et al. (1991), the level of damage during storage depend on the number of emerging adults, and the grains permitting faster and high levels of adult emergence. The hybrids which showed low levels of susceptibility can be stored for relatively longer periods of time. Resistant varieties, therefore, can be adopted as an environmentally friendly way to reduce damage by the maize weevil under the widely used storage conditions and facilities in the tropics. The parental lines of the resistant hybrids (CKPH08003, CML202/CML204, CKPH09004, CKPH08009, CKPH08010, CKPH08028, CKPH08026, CKPH08035) identified can be used as sources of resistance in breeding for resistance to postharvest insect pests. The use of resistant maize varieties leading to low grain weight loss would reduce the negative impact of the maize weevil. Host plant resistance can, therefore, be used as a vital component of an integrated pest management strategy against postharvest insect pests.

The commercial cultivars which have been bred for the mid to high altitude were the most susceptible to maize weevil attack among the hybrids evaluated. This indicates that integration of resistance to storage pests has not been routinely used by many breeding programs, thereby leading to high postharvest losses despite increased yields. According to Derera et al. (1999), most breeding programs have been addressing yield increase at the expense of storage pest resistance. Consequently, it is critical that breeding for resistance to postharvest insect pests be prioritized as equally important to safeguard famers from huge losses due to maize weevil attack. This would empower the farmers economically through reduced use of storage pesticides thus saving costs as well as avoiding negative environmental impacts associated with pesticides. Superior hybrids were identified among the genotypes for they performed far much better than the susceptible hybrid check. These can be improved further to incorporate the farmer preferred traits such as high yields and resistance to other diseases followed by release to the farmers. For instance, the CKPH08028 and CKPH08043 have been improved and released as MTPEH0701 and EMB0701 for the lowlands and midlands, respectively. These hybrids should be promoted for more adoption by farmers in those ecological zones.

The open pollinated varieties were categorized as moderately resistant to highly susceptible. The great variation observed in the germplasm evaluated forms a genetic resource base for further improvement to raise the levels of resistance to storage pest while conserving the farmer preferred traits. The classification of the landraces into resistant to highly susceptible followed a normal distribution, an indication of their variability. The great variation in response to the maize weevil attack gives evidence of the existence of genetic diversity. Hence a rich genetic resource base for breeding for resistance therefore exists. Landraces are enriched with vast genetic variability since they have not been subjected to selection over a long period of time; aiding in their adaptation to different agro-ecological niches which makes them important as genetic resources for useful traits (Yamasaki et 
al., 2007). According to Dhliwayo and Pixley (2003), inheritance for resistance to the Sitophilus zeamais is mostly additive and non-additive to a lesser extent. Landraces are considered to be important genotypes, representing the original biological material created by the process of natural selection and adapted to local growing conditions. The highly resistant landraces identified: (BRAZ 2451, SINA 21, GUAN 84, and GUAT 1162) can be used in developing inbred lines and hybrid varieties which are resistant to the maize weevil.

\section{Conclusion and Recommendations}

Resistant maize hybrids and landraces were identified from the large number of germplasm screened. This indicated that breeding for resistance to the maize weevil is not only achievable, but has already resulted in resistant hybrids being released in Kenya. These could be grown to reduce damage by the maize weevil in storage. The resistant landraces could be used as new sources of resistance. It is recommended that proper links be effected between plant entomologists and plant breeders in understanding the mechanisms of resistance and the heritability of the traits, to enhance synergism in breeding varieties with improved resistance.

\section{Acknowledgement}

The financial support by the Regional Universities Forum for Capacity building in Agriculture (RUFORUM), International Maize and Wheat Improvement Center (CIMMYT) and the Syngenta Foundation for Sustainable Agriculture through the Insect Resistant Maize for Africa (IRMA III) Project is highly acknowledged. Mr. Joel Mbithi, Mr. Patrick Gicobi, Mr. Charles Marangu, Mr. Andrew Chavangi, the technical staff at KARI-Kiboko, and Mr. David Karuri, of KARI-Embu, are recognized for their vital role in assisting with conducting of the field and laboratory studies.

\section{References}

Abate, T., Van Huis, A., \& Ampofo, J. K. O. (2000). Pest management in traditional agriculture: an African perspective. Annual Review of Entomology, 45, 631-659. http://dx.doi.org/10.1146/annurev.ento.45.1.631

Abraham, T., \& Firdissa, E. (1991). Insect pests of farm-stored maize and their management practices in Ethiopia. International Organization for Biological and Integrated Control of Noxious Animals and Plants/West Palearctic Regional Section Bulletin, 23, 45-57.

Adetunji, M. (2007). Economics of maize storage techniques by farmers in Kwara State, Nigeria. Pakistan Journal of Social Sciences, 4, 442-450.

Asawalam, E., Mosairue, S., Ekeleme, F., Wokocha, R., \& Hassanali, A. (2006). Essential oil of Vernonia amygdalina as Sitophilus zeamais Coleoptera: Curculionidae (maize weevil) protectant. Tropical and Subtropical Agroecosystems, 6, 95-102.

Byerlee, D., Eicher, C., \& Yerlee, D. (1997). Africa's Emerging Maize Revolution. In Africa's Emerging Maize Revolution: Lynne Rienner Publishers.

Derera, J., Pixley, V., \& Giga, D. P. (1999). Inheritance of maize weevil resistance in maize hybrids among lines in Southern Africa, Mexico and CIMMYT-Zimbabwe. In: Maize production technology for the future: Challenges and opportunities. Proceedings of the South Eastern and Southern African Regional Maize Conference, 21-25.

Derera, J., Pixley, V., \& Giga, D. P. (2001). Resistance of maize to the maize weevil. I. Antibiosis African Crop Science Journal, 9, 431-440. http://dx.doi.org/10.4314/acsj.v9i2.27615/ doi:10.4314/acsj.v9i2.27615

Dhliwayo, T., \& Pixley, K. (2003). Divergent selection for resistance to maize weevil to maize weevil in six maize populations. Crop science, 43, 2043-2049.

Garci'a-lara, S., Bergvinson, D., Burt, A. J., Ramput, A., Duaz-pontones, D. M., \& Arnason, J. T. (2004). The role of pericarp cell wall components in maize weevil resistance. Crop Science, 44, 546-1552.

Gemechu, K., Endashaw, B., Emana, G., Muhammad, I., Tebkew, D., Bayeh, M., \& Kifle, D. (2011). Breeding Food Legumes for Resistance to Storage Insect Pests: Potential and Limitations. Sustainability, 3, 1399-1415.

Mwololo, J. K., Mugo, S., Okori, P., Tefera, T., \& Munyiri, S. W. (2010). Genetic diversity for resistance to larger grain borer in maize hybrids and open pollinated varieties in Kenya. In Second RUFORUM Biennial Meeting (pp. 535-539). Kampala, Uganda.

Odogola, W. R. (1994). Postharvest management and storage of food legumes. Technical Systems for Agriculture. AGROTEC UNDP/OPS, Harare, Zimbabwe. 
Pereira, C., Perereira, E., Cordeiro, E., Lucia, T. D., Tótola, M., \& Guedes, R. (2009). Organophosphates resistance in the maize weevil, Sitophilus zeamais (Coleoptera: Curculionidae): magnitude and behavior. Crop Protection 28, 168-173. http://dx.doi.org/10.1016/j.cropro.2008.10.001

Pimentel, D. (2007). Area-wide pest management: environmental, economic, and food issues. In (Vreysen R. A. S. , M.J.B., Hendrichs (Eds),), Area-wide control of insect pests. (pp. 35-47). Netherlands: Springer. http://dx.doi.org/10.1007/978-1-4020-6059-5_2

Pretty, J., Toulmin, C., \& Williams, S. (2011). Sustainable intensification in African agriculture. International Journal of Agricultural Sustainability, 9, 5-24. http://dx.doi.org/10.3763/ijas.2010.0583

Sasson, A. (2012). Food security for Africa: an urgent global challenge. Agriculture and Food Security 1, 2. http://dx.doi.org/10.1186\%2F2048-7010-1-2

Siwale, J., Mbata, K., Mcrobert, J., \& Lungu, D. (2009). Comparative resistance of improved maize genotypes and Landraces to maize weevil. African Crop Science Journal, 17, 1-16.

Tefera, T., Mugo, S., \& Likhayo, P. (2011a). Effects of insect population density and storage time on grain damage and weight loss in maize due to the maize weevil Sitophilus zeamais and the larger grain borer Prostephanus truncatus. African Journal of Agricultural Research 6, 2249-2254.

Tefera, T., Mugo, S., Tende, R., \& Likhayo, P. (2011b). Methods of Screening Maize for resistance to Stem Borers and Post-harvest Insect Pets. CIMMYT, Nairobi, Kenya.

Tefera, T., Mugo, S., Likhayo, P., \& Beyene, Y. (2011c). Resistance of three-way cross experimental maize hybrids to post-harvest insect pests, the larger grain borer (Prostephanus truncatus) and maize weevil (Sitophilus zeamais). International Journal of Tropical Insect Science, 31, 3-12. http://dx.doi.org/10.1017/S1742758411000075

Thamaga-Chitja, J., Slhendriks Ortmann, G., \& Green, M. (2004). Impact of maize storage on rural household food security in northern KwaZulu- Natal. Journal of Family Ecology and Consumer Science, 32, 8-15.

Yamasaki, M., Wright, S., \& McMullen, M. (2007). Genomic screening for artificial selection during domestication and improvement in maize. Annals of Botany, 100, 967-973. 